Agro-Science Journal of Tropical Agriculture, Food, Environment and Extension Volume 12 Number 3 September 2013 pp. 25 - 34

ISSN 1119-7455

\title{
EFFECT OF PLANT POPULATION AND N FERTILIZER ON THE GROWTH AND YIELD OF BAMBARA GROUNDNUT (VIGNA SUBTERRANEA (L.) VERDC.)
}

\author{
Uchehara, C.P., Onyeonagu, C. C. ${ }^{*}$ and Asiegbu, J. E. \\ Department of Crop Science, University of Nigeria, Nsukka, Nigeria \\ "Corresponding author, e-mail: onyeonagu@yahoo.com
}

\begin{abstract}
Responses of bambara groundnut (Vigna subterranea (L.) Verdc) to 3 levels of fertilizer $N(0,50$, and $100 \mathrm{~kg} \mathrm{~N} / \mathrm{ha}$ ) and seven plant populations $(55555,63492,74074,88888,111111,148148$ and 22222 plants/ha) were studied under field conditions in Nsukka, Nigeria. The experimental design was a randomized complete block and there were three replications. Seed yield progressively increased with increasing plant population, being significantly highest at 222,222 plants/ha. The application of $100 \mathrm{~kg} \mathrm{~N} / \mathrm{ha}$ increased the total dry matter per plant compared with no application or

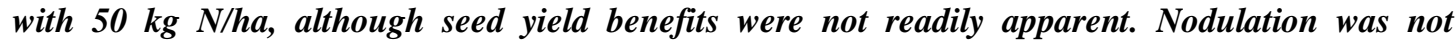
statistically influenced by $N$ treatment although zero or-low $N$ application showed a slight increase in nodulation, suggesting a lack of adequate population of the effective rhizobium in the location. Innoculation of bambara groundnut seeds with effective rhizobium strain before planting becomes necessary for good nodulation and production of the crop under Nsukka agro-ecological conditions.
\end{abstract}

Key words: Vigna subterranea, nodulation, $\mathrm{N}$-fertilizer, plant population, seed yield, dry matter yield.

\section{INTRODUCTION}

The world population is increasing at alarming rate and majority of this populous world is suffering due to insufficient and imbalance diet (Rasul et al., 2012). It has been estimated that about 790 million people are chronically under-nourished in the developing regions of the world (FAO, 1992). In these regions, the daily food consumption consists mainly of cereals, roots, tubers and fruits. Animal protein consumption is low. This low protein content of food predisposes the people to infections and such diseases as diabetes, typhoid fever and some heart and kidney diseases due to poor body defense mechanism. These regions as a result witness increased death rates and high infant mortality due to malnutrition.

Protein intake can be augmented with vegetable proteins obtained from legumes. Legumes are therefore important in improving the nutrition of the people. Some encouraging factors add to the potentials of legumes as nutritional supplements. They are less costly than animal proteins and require minimum use of resources in production. They are widely grown among the rural poor and are largely accepted traditional food in the developing regions of the world. One of such legumes is the bambara groundnut.

Bambara groundnut (Vigna subterranea (L.) Verdc) is neglected and regarded as a poor man's food and therefore had received limited research attention (Toungos et al., 2009). However, it is gaining popularity in recent times and has been identified as one of the five most important protein sources for many Africans (Vietmeyer, 1986). Bambara groundnut has been acknowledged to deserve more scientific attention (National Research Council, 1990).

The paucity of information on bambara groundnut and the potential in developing this species as a large scale field crop (Toungos et al., 2009) are compelling factors for redirecting research attention on the crop. There is a great need for designing experiments to develop package of cultural practices necessary for maximizing production of the crop. The major ways of maximizing production are by use of optimum population and fertilization. 
In most traditional farming systems, bambara groundnut is grown as an intercrop in association with one or more species. These species include cereals (rice, maize, sorghum), roots and tubers (cassava, yam), other legumes (groundnut, cowpea) and vegetables (okra, pumpkin). In intercropping systems, very wide spacing are used such as $100 \mathrm{~cm}-200 \mathrm{~cm}$, giving very low plant populations (Rachie and Sylvester, 1977). Presently, there is scarcity of information on the optimum plant population for either mixed cropping or sole cropping. For large scale production, sole cropping is often necessary and convenient. Use of optimum population will make for optimum yield. There is need, therefore, to find out the optimum plant population for vigorous bambara groundnut growth and high grain yield. The cultivation of grain legumes contributes to soil fertility through the nitrogen-fixing bacteria present in their root system. Symbiotic N-fixation alone cannot meet all the nitrogen requirement of legumes for maximum productivity (Chiezey et al., 1991) and there is need for supplemental nitrogen application. In most circumstances, bambara groundnut is grown as a low input subsistence crop and N-fertilizer recommendations are scarce (Linnemann, 1990; Linnemann and Azam-ali, 1992). Its production still remains marginal. In Nigeria, investigations to ascertain the level of supplemental $\mathrm{N}$ needed for optimum yield of bambara groundnut are scanty as the crop has been most often grown without fertilizer. This necessitates that research be carried out to find out the amount of fertilizer $\mathrm{N}$ needed for optimum growth and production under tropical derived savannah conditions of Nsukka.

The investigation here reported was therefore based on the following objectives;

1. Determination of an optimum plant population for bambara groundnut under the Nsukka agroecological conditions, and

2. Assessment of the N-fertilizer needs of bambara groundnut

\section{MATERIALS AND METHODS}

The experiment was carried out in the Teaching and Research Farm of the Department of Crop Science, University of Nigeria, Nsukka. Nsukka is located within latitude $06^{\circ} 52^{\prime} \mathrm{N}$ and longitude $07^{\circ} 24^{\prime} \mathrm{E}$ and at an altitude of 447 metres above sea level The soil is an ultisol of the Nkpologu series (Jungerius, 1964). The experimental site had previously been under cassava cultivation but was under a one-year fallow at the time it was cleared and used for this experiment.

\section{Land Preparation and Soil Samp1ing}

Land was cleared on the 29th of April, 1992 and ploughed on the 4th of May, 1992. Lime as calcium carbonate $(\mathrm{CaCO} 3)$ was given as blanket application on 10th May 1992 at the rate of $1.5 \mathrm{t} / \mathrm{ha}$. The field was marked into three blocks of $64 \mathrm{~m} \times 2.5 \mathrm{~m}$ each. Each block was then further divided into 21 experimental plots measuring $2 \mathrm{~m} \times 2.5 \mathrm{~m}$. Soil samples to a depth of $15.0 \mathrm{~cm}$ were taken from different representative locations of the site with soil auger. The samples collected were bulked and thoroughly mixed to obtain composite sample from which, a sub sample was taken for chemical analysis.

\section{Experimental design and treatment allocation}

The experiment was a $7 \times 3$ factorial laid out in a randomized complete block design and there were three replications. There were 7 plant populations of:

$$
\begin{aligned}
& 40 \mathrm{~cm} \times 45 \mathrm{~cm}=55,555 \text { plants/ha }\left(D_{1}\right) \\
& 35 \mathrm{~cm} \times 45 \mathrm{~cm}=63,492 \text { plants/ha }\left(D_{2}\right) \\
& 30 \mathrm{~cm} \times 45 \mathrm{~cm}=74,074 \text { plants/ha }\left(D_{3}\right) \\
& 25 \mathrm{~cm} \times 45 \mathrm{~cm}=88,888 \text { plants/ha }\left(D_{4}\right) \\
& 20 \mathrm{~cm} \times 45 \mathrm{~cm}=111,111 \text { plants/ha }\left(D_{5}\right) \\
& 15 \mathrm{~cm} \times 45 \mathrm{~cm}=148,148 \text { plants } / \mathrm{ha}\left(\mathrm{D}_{6}\right) \\
& 10 \mathrm{~cm} \times 45 \mathrm{~cm}=222,222 \text { plants } / \mathrm{ha}\left(\mathrm{D}_{7}\right) \\
& \text { and } 3 \mathrm{~N}-\text { fertilizer rates of: } 0 \mathrm{~kg} \mathrm{~N} / \mathrm{ha} \\
&\left(\mathrm{N}_{0}\right), 50 \mathrm{~kg} \mathrm{~N} / \mathrm{ha}\left(\mathrm{N}_{1}\right) \text { and } 100 \mathrm{~kg} \mathrm{~N} / \mathrm{ha}\left(\mathrm{N}_{2}\right) .
\end{aligned}
$$

There were 21 treatment combinations which were allocated to each of the 3 blocks completely at random.

\section{Planting and Supplying}

Seeds of Yaudu local were hand-planted at the appropriate spacing for each plot. Two seeds were sown per hole. After some few days following planting, the missing stands were supplied.

\section{Maintenance Operations}

Three hoe-weeding operations were done during the life of the crop. The first weeding was done at 15 days after planting and the others at 49 and 142 days after planting. The weeding done at 49 days after planting was accompanied by earthing up to enhance the penetration of the gynophores into the soil. Phosphorus as single superphosphate (18\%. $\left.\mathrm{P}_{2} \mathrm{O}_{5}\right)$ and potassium as muriate of potash $(60 \%$ $\mathrm{K}_{2} \mathrm{O}$ ) as basal dressings were applied to the plots at 21 days after planting at the rate of $40 \mathrm{~kg} \mathrm{P} / \mathrm{ha}$ and $80 \mathrm{~kg} \mathrm{~K} / \mathrm{ha}$, respectively. Nitrogen as urea $(46 \% \mathrm{~N})$ was applied in a single dose according to the corresponding treatment combination for each of the plots. Application was also at 21 days after planting. In all cases, fertilizer application was done using the band method of application. 


\section{Records of agronomic measurements}

Measurements were taken of number of leaves per plant, number of branches per plant and leaf, stem and root dry matter. Plant height was measured by taking the height of selected six plants from the middle row using a metre rule. This was done in situ from ground level to the apex of the tallest branch. Leaf area measurements were obtained using Delta automatic leaf area metre model MK2 GMT. Canopy diameter was studied by measuring the vertical and the horizontal diameter per plant. A total of six plants per plot were used for the canopy measurements. The yield parameters measured include number of pods per plant, number of seeds per pod, seed weight per plant, 100 -seed weight, and shelling percentage was calculated as follows:

\section{$\frac{\text { Weight of shell }}{\text { Weight of seed }+ \text { shell }} \times 100$}

Growth analysis was conducted on two occasions. One was at 60 days after planting and the other at 75 days after planting. On each occasion, two plants per plot were sampled from the middle rows. The plants were carefully dug up, making sure to recover the roots as much as possible. The plants were cleaned and separated into leaves, stem, root, nodules and pod fractions. These plant fractions were packed into labeled paper bags and dried to a constant weight in the oven at $80^{\circ} \mathrm{C}$.

Weather records of rainfall, radiation, soil temperature, air (ambient) temperature, wind speed, sunshine hours and relative humidity were got from the Department of Crop Science Agro-meteorological station.

Soil samples collected before commencement of the experiment were analyzed for $\mathrm{pH}$, nitrogen, carbon, organic matter and the concentration of phosphorus, calcium and magnesium. The soil $\mathrm{pH}$ was determined in distilled water and in $1 \mathrm{~N} \mathrm{KC1,} \mathrm{using} \mathrm{a} \mathrm{soil:}$ water ratio of 1:2.5. The suspension was thoroughly stirred and allowed to stand for 30 mins after which the $\mathrm{pH}$ was determined using an electronic $\mathrm{pH}$ metre. Total nitrogen was determined by micro Kjeldahl digestion method described by A.O.A.C. (1980). The cations (Ca, $\mathrm{Mg}$ ) were determined by the atomic absorption method as outlined in the Analysis of the Official Analytical Chemists (A.O.A.C., 1980).

\section{RESULTS}

The soil at the experimental site was texturally a sandy clay loam and was acidic (Table 1). Application of $1.6 \mathrm{t} / \mathrm{ha}$ of calcium carbonate brought the soil $\mathrm{pH}$ to 5.5 at 9 days after lime application. The soil was considered low in total $\mathrm{N}$, organic matter, $\mathrm{P}$ and exchangeable bases

The monthly rainfall was low for most months compared with the value for the preceding ten years, except in September when rainfall was particularly high (Table 2), it was exceptionally low in the month of August. The temperatures and radiation values appeared normal compared with the mean over many years.

The total dry matter accumulation in the intermediate plant population of 88,888 or $111,111 \mathrm{plant} / \mathrm{ha}$ was higher than those for other plant populations (Table 3). Fertilizer N application and the interaction between $\mathrm{N}$ fertilizer and plant population did not produce any statistically significant effects.

Dry matter partitioned to the stem and leaf were higher with $100 \mathrm{~kg} \mathrm{~N} / \mathrm{ha}$ application than where $\mathrm{N}$ was not applied, but there were no significant differences between the application of $100 \mathrm{~kg} \mathrm{~N} / \mathrm{ha}$ and application of $50 \mathrm{~kg} \mathrm{~N} / \mathrm{ha}$ (Table. 4). Differences in root, pod and total dry matter accumulation at 57 DAP did not differ statistically. The intermediate plant populations of 88,888 and 111,111 plants/ha accumulated higher dry matter in most plant parts than other plant population treatments except 148,148 plants/ha. The total plant dry matter (g/plant) was highest with 111,111 plants/ha although the value was not significantly higher than those of 148,148 and 88,888 plants/ha. There were no significant interactions between plant population and $\mathrm{N}$ treatments.

The number of leaves produced per plant at 57 days after planting was higher with $100 \mathrm{~kg}$ $\mathrm{N} /$ ha treatment compared with where no nitrogen was applied or with where $50 \mathrm{~kg} \mathrm{~N} / \mathrm{ha}$ was applied (Table 5). Differences in number of leaves per plant due to plant population did not attain statistical significance. Leaf area per plant did not vary significantly with $\mathrm{N}$ treatment or with variation in plant population. 
Table 1: Mechanical and chemical properties of the soil for the field experiment.

\begin{tabular}{ll}
\hline Soil properties & Values \\
\hline Mechanical properties (\%) & 60 \\
Coarse sand & 12 \\
Fine sand & 26.0 \\
clay & 2 \\
silt & Sand clay loam \\
Textural class & \\
Chemical properties $(\%)$ & 0.06 \\
\hline Nitrogen & 1.0 \\
Organic carbon & 0.60 \\
Exchangeable calcium meq/100 g soil & 0.80 \\
Exchangeable magnesium meq/100 g soil & 44 \\
Available phosphorus meq/100 g soil & 4.6 \\
pH 1:2.5 water: soil & 4.0 \\
pH 1:2.5 KCI: soil & 5.5 \\
pH 1:2.5 water: soil $(9$ days after liming) & \\
\hline
\end{tabular}

Table 2: Mean weather records for the site of the experiment from January 1992 to January 1993

\begin{tabular}{|c|c|c|c|c|c|c|c|c|c|c|c|c|c|}
\hline $\begin{array}{l}\text { Climatological } \\
\text { parameters }\end{array}$ & Jan. & Fed & Mar & Apr & May & June & July & Aug & Sep & Oct & Nov & Dec & Jan \\
\hline Total rainfall $(\mathrm{mm})$ & 0 & 0 & 47.3 & 110.7 & 209.3 & 126.0 & 115.9 & 80.0 & 456.8 & 177.3 & 61.3 & 0 & 0 \\
\hline Rain days & 0 & 0 & 2 & 4 & 12 & 12 & 18 & 19 & 19 & 12 & 3 & 0 & 0 \\
\hline Total radiation & 666.7 & 821.8 & 640.8 & 706.2 & 644.7 & 522.9 & 463.5 & 416.4 & 510.8 & 569.3 & 650.5 & 760.1 & 664.8 \\
\hline Relative humidity (\%) & 47 & 44.5 & 56.5 & 68 & 88 & 72 & 69 & 60.5 & 55.5 & 86 & 79.5 & 50 & 43.8 \\
\hline Soil temp. $\left(\max { }^{\circ} \mathrm{C}\right)$ & 32.7 & 42.5 & 40.0 & 38.5 & 35.2 & 32.6 & 31.6 & 29.9 & 30.9 & 31.3 & 32.0 & 37.7 & 33.0 \\
\hline Soil temp. $\left(\min { }^{\circ} \mathrm{C}\right)$ & 26.4 & 26.4 & 30.1 & 30.3 & 28.3 & 27.0 & 25.8 & 24.9 & 25.5 & 26.2 & 28.0 & 27.5 & 26.8 \\
\hline
\end{tabular}

Table 3: Effects of plant population and $\mathrm{N}$ fertilizer rates on total plant dry matter (g/plant) at 36 DAP+.

\begin{tabular}{|c|c|c|c|c|c|c|c|c|}
\hline \multicolumn{9}{|c|}{ Plant population } \\
\hline $\mathrm{N}$ rates $(\mathrm{kg} / \mathrm{ha})$ & $\mathrm{D}_{1}$ & $\mathrm{D}_{2}$ & $\mathrm{D}_{3}$ & $\mathrm{D}_{4}$ & $\mathrm{D}_{5}$ & $\mathrm{D}_{6}$ & $\mathrm{D}_{7}$ & Mean \\
\hline 0 & 4.8 & 6.7 & 5.6 & 4.5 & 5.2 & 5.7 & 4.0 & 5.2 \\
\hline 50 & 4.0 & 4.9 & 5.8 & 5.7 & 6.3 & 5.6 & 3.5 & 5.1 \\
\hline 100 & 3.9 & 5.5 & 4.2 & 7.6 & 6.4 & 5.6 & 2.9 & 5.1 \\
\hline Mean & 4.1 & 5.7 & 5.2 & 5.9 & 6.0 & 5.6 & 3.5 & 5.2 \\
\hline $\mathrm{LSD}_{0.05}$ for $2 \mathrm{~N}$ means & N.S & & & & & & & \\
\hline $\mathrm{LSD}_{0.05}$ for 2 population means & 1.7 & & & & & & & \\
\hline $\mathrm{LDS}_{0.05}$ for $\mathrm{N} x$ population means & N.S & & & & & & & \\
\hline
\end{tabular}

$\mathrm{D}_{1}=55,555$ plants $/$ ha $; \mathrm{D}_{2}=63,492$ plants $/$ ha $; \mathrm{D}_{3}=74,074$ plants $/$ ha $; \mathrm{D}_{4}=88,888$ plants $/$ ha $; \mathrm{D}_{5}=111,111$ plants $/$ ha $; \mathrm{D}_{6}=148,148$ plants/ha; $\mathrm{D}_{7}=222,222$ plants/ha.

Except for a higher number of nodules with 111,111 plants/ha at 36 DAP compared with 148148,55555 and 74,074 plants/ha, plant population did not clearly affect nodule number on per plant basis (Table 6). Nodule dry weight appeared higher with 63492, 74074, 88888 and 111111 plants/ha compared with 148148 and 222222 plants/ha. At 57 DAP, although no clear statistical effects were obtained with varying plant populations, number of nodules appeared highest with 148148 and 111111 plants/ha compared with the others. Generally, there were no clear effects of $\mathrm{N}$ treatments on number of nodules and nodule weight at both 36 and 57 DAP. However, at the early stage of plant growth (36 DAP), the number of nodules and dry weight appeared highest with no nitrogen treatment. 
Table 4: Effects of plant population and fertilizer $N$ rates on dry matter of plant parts (stem, leaf, root, and pod) and total plant dry matter (g/plant) at 57 DAP ${ }^{+}$

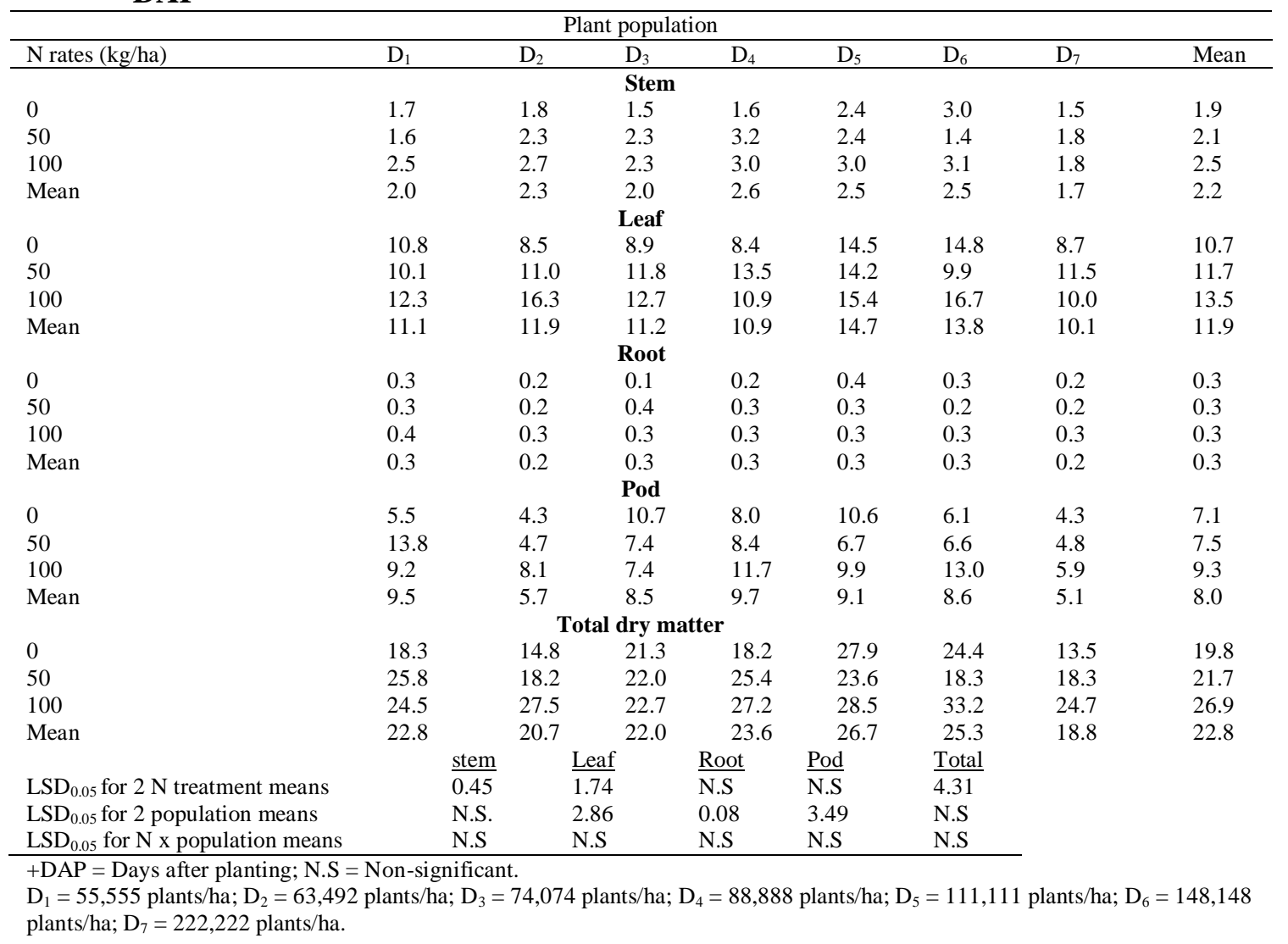

Table 5: Effects of plant population and fertilizer $\mathbf{N}$ rates on leaf number per plant and leaf area $\left(\mathrm{cm}^{2}\right)$ per plant at $57 \mathrm{DAP}^{+}$

\begin{tabular}{|c|c|c|c|c|c|c|c|c|}
\hline \multicolumn{9}{|c|}{ Plant population } \\
\hline $\mathrm{N}$ rates $(\mathrm{kg} / \mathrm{ha})$ & D1 & D2 & D3 & D4 & D5 & D6 & D7 & Mean \\
\hline \multicolumn{9}{|l|}{ Leaf number } \\
\hline 0 & 86.7 & 77.8 & 59.3 & 56.3 & 98.0 & 91.7 & 71.3 & 77.4 \\
\hline 50 & 85.3 & 88.6 & 83.0 & 84.7 & 78.3 & 98.3 & 56.7 & 81.7 \\
\hline 100 & 87.7 & 99.8 & 80.0 & 111.7 & 108.7 & 106.7 & 77.3 & 95.6 \\
\hline Mean & 85.6 & 87.1 & 74.1 & 84.2 & 95.0 & 98.9 & 68.4 & 84.9 \\
\hline \multicolumn{9}{|l|}{ Leaf area } \\
\hline 0 & 1656.3 & 1575.0 & 6773.0 & 1152.0 & 1683.0 & 2060.3 & 1318.0 & 2316.8 \\
\hline 50 & 1843.0 & 1667.3 & 1560.0 & 1746.0 & 1802.0 & 1909.3 & 1611.3 & 1734.1 \\
\hline 100 & 1899.3 & 2175.3 & 1770.3 & 2208.7 & 2454.3 & 2449.0 & 1765.7 & 2103.2 \\
\hline \multirow[t]{2}{*}{ Mean } & 1799.6 & 1805.9 & 3367.8 & 1702.2 & 1979 & 2139.6 & 1565.0 & 2051.4 \\
\hline & & & \multicolumn{3}{|c|}{$\underline{\text { Leaf Number }}$} & \multicolumn{3}{|c|}{$\underline{\text { Leaf area }}$} \\
\hline \multicolumn{3}{|c|}{$\mathrm{LSD}_{0.05}$ for 2 fertilizers means } & \multicolumn{3}{|c|}{13.8} & \multicolumn{3}{|c|}{ N.S } \\
\hline \multicolumn{3}{|c|}{$\mathrm{LSD}_{0.05}$ for 2 plant population } & \multicolumn{3}{|c|}{ N.S } & \multicolumn{3}{|c|}{ N.S } \\
\hline \multicolumn{3}{|c|}{$\mathrm{LSD}_{0.05}$ for $\mathrm{N} x$ population } & \multicolumn{3}{|c|}{ N.S } & \multicolumn{3}{|c|}{ N.S } \\
\hline
\end{tabular}

+ DAP $=$ Days after planting

$\mathrm{D}_{1}=55,555$ plants $/$ ha; $\mathrm{D}_{2}=63,492$ plants $/$ ha; $\mathrm{D}_{3}=74,074$ plants $/$ ha; $\mathrm{D}_{4}=88,888$ plants $/$ ha; $\mathrm{D}_{5}=111,111$ plants $/$ ha $; \mathrm{D}_{6}=148,148$ plants/ha; $\mathrm{D}_{7}=222,222$ plants $/$ ha. 
Table 6: Effects of plant population and fertilizer $\mathbf{N}$ rates on the number and dry weight of nodules per plant at 36 and 57 days after planting.

\begin{tabular}{|c|c|c|c|c|c|c|c|c|}
\hline \multicolumn{9}{|c|}{ Plant population } \\
\hline $\mathrm{N}$ rates $(\mathrm{kg} / \mathrm{ha})$ & $D_{1}$ & $\mathrm{D}_{2}$ & $\mathrm{D}_{3}$ & $\mathrm{D}_{4}$ & $D_{5}$ & $D_{6}$ & $\mathrm{D}_{7}$ & Mean \\
\hline \multicolumn{9}{|l|}{ At 36 DAO } \\
\hline \multicolumn{9}{|l|}{ Nodule number: } \\
\hline 0 & 9.8 & 24.3 & 16.3 & 17.0 & 32.3 & 15.0 & 18.7 & 19.1 \\
\hline 50 & 10.7 & 8.7 & 18.0 & 28.0 & 13.3 & 4.9 & 16.3 & 14.2 \\
\hline 100 & 15.0 & 22.3 & 7.0 & 10.0 & 21.3 & 13.8 & 30.3 & 17.1 \\
\hline Mean & 11.8 & 18.4 & 13.8 & 18.3 & 22.3 & 11.1 & 21.8 & 16.8 \\
\hline \multicolumn{9}{|l|}{ Nodule dry weight: } \\
\hline 0 & 0.01 & 0.05 & 0.06 & 0.05 & 0.04 & 0.01 & 0.02 & 0.04 \\
\hline 50 & 0.02 & 0.01 & 0.04 & 0.03 & 0.02 & 0.01 & 0.01 & 0.02 \\
\hline 100 & 0.02 & 0.03 & 0.01 & 0.01 & 0.02 & 0.02 & 0.01 & 0.02 \\
\hline Mean & 0.02 & 0.03 & 0.03 & 0.03 & 0.03 & 0.01 & 0.01 & 0.02 \\
\hline \multicolumn{9}{|l|}{ At 57 DAP } \\
\hline \multicolumn{9}{|l|}{ Nodule number } \\
\hline 0 & 7.3 & 3.3 & 9.8 & 10.3 & 20.7 & 21.0 & 6.7 & 10.7 \\
\hline 50 & 8.0 & 12.7 & 6.3 & 10.3 & 8.7 & 12.3 & 16.7 & 10.8 \\
\hline 100 & 4.7 & 16.8 & 4.3 & 7.3 & 10.0 & 6.3 & 5.3 & 7.8 \\
\hline Mean & 0.01 & 0.01 & 0.02 & 0.04 & 0.02 & 0.04 & 0.02 & 0.02 \\
\hline \multicolumn{9}{|l|}{ Nodule dry weight: } \\
\hline 0 & 0.01 & 0.00 & 0.02 & 0.02 & 0.03 & 0.07 & 0.02 & 0.02 \\
\hline 50 & 0.02 & 0.01 & 0.04 & 0.06 & 0.01 & 0.03 & 0.03 & 0.03 \\
\hline 100 & 0.03 & 0.02 & 0.02 & 0.03 & 0.04 & 0.01 & 0.02 & 0.02 \\
\hline \multirow[t]{4}{*}{ Mean } & 0.01 & 0.01 & 0.02 & 0.04 & 0.02 & 0.04 & 0.02 & 0.02 \\
\hline & \multicolumn{5}{|c|}{36 DAP } & \multicolumn{3}{|c|}{57 DAP } \\
\hline & \multicolumn{4}{|c|}{ Nodule weight } & \multirow{2}{*}{\multicolumn{2}{|c|}{ Nodule number }} & \multirow{2}{*}{\multicolumn{2}{|c|}{ Nodule weight }} \\
\hline & \multicolumn{2}{|c|}{ Nodule number } & & & & & & \\
\hline $\mathrm{LSD}_{0.05}$ for $2 \mathrm{~N}$ means & & \multicolumn{2}{|l|}{ N.S } & \multicolumn{2}{|c|}{ N.S } & \multicolumn{2}{|c|}{ N.S } \\
\hline $\mathrm{LSD}_{0.05}$ for 2 population means & \multicolumn{2}{|l|}{8.75} & \multicolumn{2}{|l|}{ N.S } & \multicolumn{2}{|c|}{ N.S } & \multicolumn{2}{|c|}{ N.S } \\
\hline $\mathrm{LSD}_{0.05}$ for $\mathrm{N} \mathrm{x}$ population means & 15.16 & & N.S & & \multicolumn{2}{|c|}{ N.S } & \multicolumn{2}{|c|}{ N.S } \\
\hline
\end{tabular}

Table 7: Effects of plant population and fertilizer $N$ rates on plant height $((\mathrm{cm})$ and on vertical and horizontal canopy diameters (cm/plant) of bambara groundnut at 57 DAP $^{+}$

\begin{tabular}{|c|c|c|c|c|c|c|c|c|}
\hline \multicolumn{9}{|c|}{ Plant population } \\
\hline $\mathrm{N}$ rates $(\mathrm{kg} / \mathrm{ha})$ & $\mathrm{D}_{1}$ & $\mathrm{D}_{2}$ & $\mathrm{D}_{3}$ & $\mathrm{D}_{4}$ & $\mathrm{D}_{5}$ & $\mathrm{D}_{6}$ & $\mathrm{D}_{7}$ & Mean \\
\hline \multicolumn{9}{|l|}{ Plant height: } \\
\hline 0 & 14.8 & 16.2 & 12.4 & 13.7 & 18.0 & 17.0 & 19.9 & 16.1 \\
\hline 50 & 14.9 & 17.9 & 18.3 & 15.6 & 14.2 & 14.5 & 18.3 & 16.2 \\
\hline 100 & 17.7 & 13.7 & 14.1 & 17.2 & 18.6 & 16.0 & 17.5 & 16.4 \\
\hline Mean & 15.8 & 15.9 & 14.9 & 15.5 & 16.9 & 15.9 & 18.6 & 16.2 \\
\hline \multicolumn{9}{|l|}{ Vertical canopy diameter: } \\
\hline 0 & 34.1 & 36.7 & 34.4 & 32.6 & 28.6 & 31.5 & 24.4 & 31.7 \\
\hline 50 & 28.8 & 42.5 & 36.2 & 35.6 & 34.3 & 28.5 & 31.7 & 33.9 \\
\hline 100 & 41.2 & 36.2 & 42.2 & 40.7 & 36.3 & 32.3 & 26.4 & 36.5 \\
\hline Mean & 34.7 & 38.5 & 37.6 & 36.3 & 33.1 & 30.8 & 27.5 & 34.1 \\
\hline \multicolumn{9}{|l|}{ Horizontal canopy diameter: } \\
\hline 0 & 39.1 & 37.2 & 34.9 & 34.6 & 38.8 & 42.2 & 40.9 & 38.2 \\
\hline 50 & 43.5 & 46.6 & 36.9 & 41.6 & 41.3 & 45.2 & 45.6 & 43.0 \\
\hline 100 & 45.5 & 45.5 & 44.2 & 44.7 & 42.8 & 42.8 & 46.4 & 45.0 \\
\hline \multirow[t]{2}{*}{ Mean } & 42.7 & 43.1 & 38.6 & 41.3 & 40.9 & 43.4 & 44.3 & 42.0 \\
\hline & & & & & $\begin{array}{l}\text { Plant } \\
\text { Height }\end{array}$ & $\begin{array}{l}\text { Vertical } \\
\text { canopy } \\
\text { diameter }\end{array}$ & \multicolumn{2}{|c|}{$\begin{array}{l}\text { Horizontal } \\
\text { canopy } \\
\text { diameter }\end{array}$} \\
\hline $\mathrm{LSD}_{0.05}$ for $2 \mathrm{~N}$ means & & & & & N.S & 2.99 & & \\
\hline $\mathrm{LSD}_{0.05}$ for 2 population means & & & & & N.S & 4.56 & & \\
\hline $\mathrm{LSD}_{0.05}$ for $\mathrm{N} x$ population means & & & & & N.S & N.S & & \\
\hline
\end{tabular}


Table 8: Effects of plant population and fertilizer $\mathbf{N}$ rates on the number of Pods per plant and seed number per pod after harvest

\begin{tabular}{|c|c|c|c|c|c|c|c|c|}
\hline \multicolumn{9}{|c|}{ Plant population } \\
\hline $\mathrm{N}$ rates $(\mathrm{kg} / \mathrm{ha})$ & $\mathrm{D}_{1}$ & $\mathrm{D}_{2}$ & $\mathrm{D}_{3}$ & $\mathrm{D}_{4}$ & $\mathrm{D}_{5}$ & $\mathrm{D}_{6}$ & $\mathrm{D}_{7}$ & Mean \\
\hline \multicolumn{9}{|l|}{ Pod number per plant } \\
\hline 0 & 36.1 & 32.5 & 23.9 & 28.4 & 30.0 & 27.1 & 22.2 & 28.6 \\
\hline 50 & 27.2 & 38.3 & 24.5 & 21.9 & 20.0 & 18.2 & 36.2 & 26.6 \\
\hline 100 & 38.0 & 38.1 & 48.5 & 24.9 & 22.4 & 24.0 & 21.4 & 31.1 \\
\hline Mean & 26.6 & 23.1 & 24.1 & 25.1 & 32.3 & 36.3 & 33.8 & 28.8 \\
\hline \multicolumn{9}{|l|}{ Seed number per pod: } \\
\hline 0 & 1.1 & 1.1 & 1.0 & 1.2 & 1.2 & 1.4 & 1.0 & 1.1 \\
\hline 50 & 0.9 & 1.3 & 1.0 & 1.7 & 1.1 & 1.3 & 1.0 & 1.1 \\
\hline 100 & 0.8 & 0.9 & 1.8 & 1.2 & 1.1 & 1.3 & 1.0 & 1.1 \\
\hline \multirow[t]{2}{*}{ Mean } & 0.9 & 1.1 & 1.2 & 1.4 & 1.2 & 1.3 & 1.0 & 1.1 \\
\hline & \multicolumn{2}{|c|}{ Pod number/ plant } & \multicolumn{6}{|c|}{$\underline{\text { Seed number/ plant }}$} \\
\hline $\mathrm{LSD}_{0.05}$ for $2 \mathrm{~N}$ means & \multicolumn{2}{|c|}{$\overline{N . S}$} & \multicolumn{6}{|c|}{$\overline{N . S}$} \\
\hline $\mathrm{LSD}_{0.05}$ for 2 population means & \multicolumn{2}{|l|}{ N.S } & \multicolumn{2}{|c|}{ N.S } & & & & \\
\hline $\begin{array}{l}\mathrm{LSD}_{0.05} \text { for } \mathrm{N} x \text { population } \\
\text { means }\end{array}$ & \multicolumn{2}{|l|}{ N.S } & \multicolumn{2}{|c|}{ N.S } & & & & \\
\hline
\end{tabular}

Table 9: Effects of plant population and fertilizer $\mathrm{N}$ rates on seed yield (kg/ha) and 100 seed weight (g) of bambara groundnut

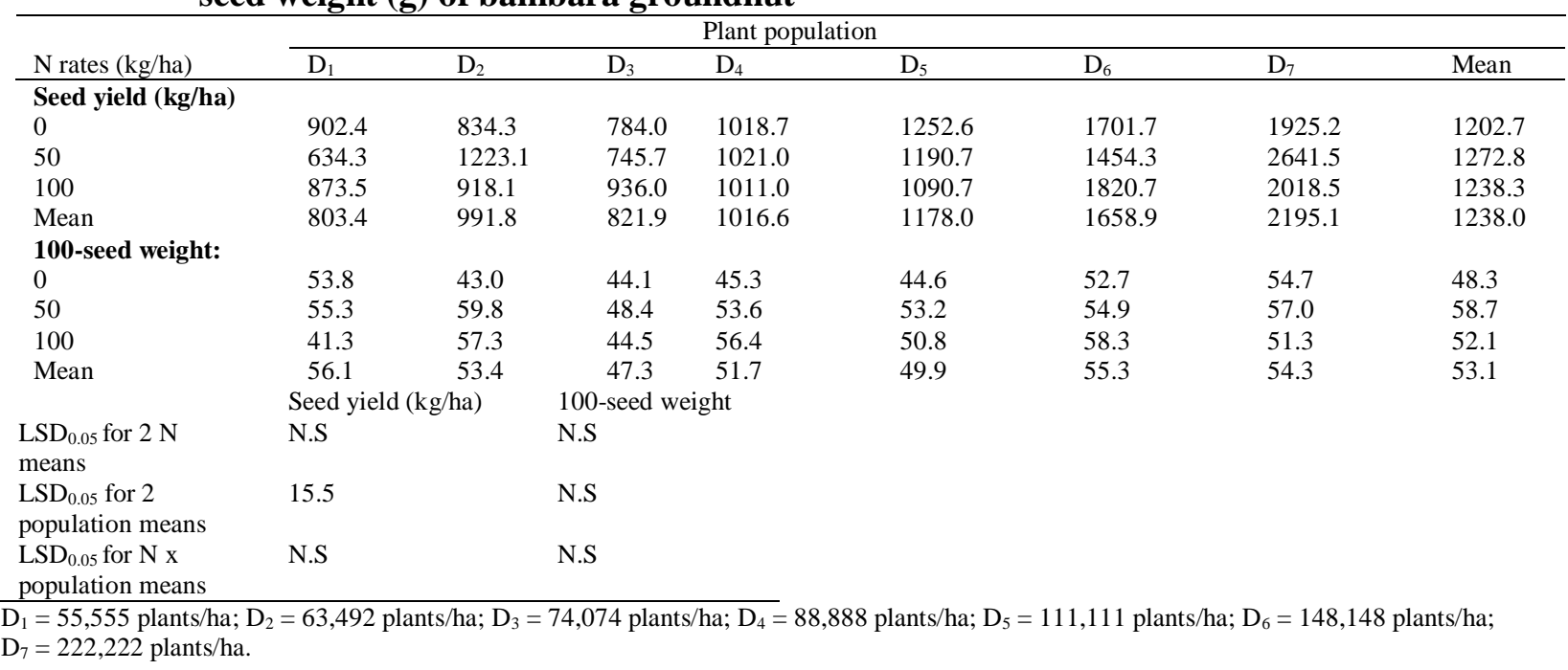

Nitrogen application and plant population did not influence bambara groundnut plant height (Table 7). Vertical canopy diameter was highest with 63,492 plants/ha which had statistically similar values as 55555, 74074 and 88888 plants/ha. Very high populations of 222222, 148148 and 111111 plants/ha had the least vertical canopy diameter values in that order. Nitrogen treatment of $100 \mathrm{~kg} \mathrm{~N} / \mathrm{ha}$ gave a higher vertical canopy diameter compared with $0 \mathrm{~kg} \mathrm{~N} / \mathrm{ha}$ treatment but not more than $50 \mathrm{~kg} \mathrm{~N} / \mathrm{ha}$ treatment. Except for a higher horizontal canopy diameter with 222,222 plants/ha compared with 74,074 plants/ha only, plant population treatments did not clearly affect the horizontal canopy diameter. Nitrogen treatment did not statistically affect the horizontal canopy diameter, although the value appeared to increase with increasing $\mathrm{N}$ treatment.

Number of pods per plant was not clearly affected by $\mathrm{N}$ treatments or by plant population (Table 8). Similarly, number of seeds per pod was not significantly affected by $\mathrm{N}$ treatment or plant population. The nitrogen $\mathrm{x}$ plant population interaction effects were non-significant.

Seed yield (kg/ha) increase with $\mathrm{N}$ application was slight and did not attain statistical 
significance (Table 9). However, yield was progressively increased by increased plant population up to the highest population used. The 100 -seed weight was not influenced significantly by $\mathrm{N}$ treatment or plant population. $\mathrm{N}$ fertilization did not significantly influence seed yield or 100seed weight within each plant population.

\section{DISCUSSION \\ Bambara Groundnut Responses to Plant population}

An optimum plant population is considered the foundation for having increased seed yield (Rasul et al., 2012). From literature, the recommended plant populations include 83,720 plants/ha and 167,400 plants/ha (Malawi Government, 1970), 148,148 plants/ha or 222,222 plants/ha (Johnson, 1968). In the present study, the population of 222,222 plants/ha gave the highest seed yield and this agrees with recommendations by Johnson (1968). Disparities in the reported optimum population could possibly be accounted for by variability in varieties, soil type and the general environmental conditions. Dry matter per plant increased with plant population but not beyond the plant population of 111,111 plants/ha, which appeared to be the optimum population for total dry matter accumulation.

The least plant population of 55,555 plants/ha gave the highest root and pod dry matter fractions per plant, apparently as a result of a wider soil volume for root growth and nutrient absorption for individual plant development. It has been reported that where plants are grown at high populations, the root system of individual plants become small and less extensive because of the smaller soil volume from which to extract nutrients (Harper, 1983).

The inability of the bambara groundnut to increase in height with increase in plant population could be accounted for by its growth habit. The stems are short, prostrate and profusely branched and root at the nodes (Doku, 1969), encouraging lateral expansion rather than vertical growth.

Research at the University of Nothingham indicated that denser populations than 140,000 and 220,000 plants/ha may be required to maximize the amount of radiation intercepted by the crop (Karim, 1990; Rowland, 1993). This could be the reason for the non-significant effect of plant population observed on the extent of plant ground cover in the present investigation. Chiezey et al. (1991) had observed that lesser pod number per plant were obtained with increasing plant population in soybean and attributed that to interplant competition for the light, nutrients and water. In the present study, it was not readily clear why the plant population did not clearly influence the number of pods per plant.

The highest grain yield was obtained at highest plant population of 222,222 plants/ha, indicating that probably the optimum plant population for grain yield had not been reached. Similar increases in grain yield with increasing plant population have also been reported in soybean (Quayum, 1983; Chiezey et al., 1991; Toungos et al., 2009) and in cowpea (Ndor et al., 2012). The 100-seed weight was not influenced by plant population. Chiezey et al. (1991) similarly reported that plant population did not influence seed size in soybean. The weight of 100 seeds which Goli and Ng (1988) recommended as ideal for physical appearance and for high grade grain was $46.2 \mathrm{~g}$. However, the 100-seed weight in the present study was higher than $46.2 \mathrm{~g}$.

\section{Bambara Groundnut Responses to Nitrogen Fertilization}

Nodulation was generally low irrespective of whether $\mathrm{N}$ was applied or not. This suggested low population of the effective native rhizobium in the soil of the location since Nsukka does not have a long previous history of bambara groundnut cultivation. There seems a need for inoculation of seeds with effective rhizobium for good nodulation and nitrogen economy.

Abate (2008) had observed that as the levels of available nitrogen increased in the soil, the amount of nitrogen fixed symbiotically generally decreased. The trend of decline in the nodule number and nodule dry weight with $\mathrm{N}$ application might probably be connected with the depressed symbiotic activity due to $\mathrm{N}$ applications. In cowpea, increased application of fertilizer $\mathrm{N}$ resulted in decreased nodule number and nodule weight and that situation was considered common with legumes (Khaliger, 1987). Plant dry matter was increased by $\mathrm{N}$ application up to the rate of $100 \mathrm{~kg} \mathrm{~N} /$ ha showing that fertilizer $\mathrm{N}$ was not in itself toxic to bambara groundnut as Allos and Bartholomew (1959) had also noted for legumes with fertilizer $\mathrm{N}$ application, except that under such high $\mathrm{N}$ application, the need for biological $\mathrm{N}$ fixation was obviated. Similarly, Summerfield et al. (1977) reported that application of fertilizer $\mathrm{N}$ at the rate of $100-200 \mathrm{~kg} \mathrm{~N} / \mathrm{ha}$ to cowpea compared with where no $\mathrm{N}$ or low rates were applied increased the leaf area and dry matter yield. However, the higher dry matter obtained 
with high $\mathrm{N}$ treatment in this study did not translate into higher grain yield since number of pods per plant, seed yield $\mathrm{kg} / \mathrm{ha}$ and 100 -seed weight were not significantly increased by $\mathrm{N}$ application. Since the grain is the economic yield, incurring more expenses through fertilizer application might be unadvisable under the circumstance.

\section{SUMMARY AND CONCLUSION}

In the present study, the plant population of 111,111 plants/ha gave the best individual plant development while vertical ground cover was high with 63,492 plants/ha. Seed yield $(\mathrm{kg} / \mathrm{ha})$ increased progressively as plant population increased from the lowest population to the highest population and the highest plant population of 222,222 plants/ha gave significantly the highest seed yield of 2195.1 $\mathrm{kg} / \mathrm{ha}$.

The application of fertilizer $\mathrm{N}$ to bambara groundnut increased the total dry matter yield per plant at $100 \mathrm{~kg} \mathrm{~N} / \mathrm{ha}$ compared with no application or at $50 \mathrm{~kg} \mathrm{~N} / \mathrm{ha}$, although seed yield benefits were not readily apparent. Nodulation was not statistically increased by $\mathrm{N}$ treatment although no $\mathrm{N}$ application or low $\mathrm{N}$ application showed a slight increase in nodulation. This may suggest the lack of adequate population of the effective rhizobium in the location as Nsukka has not a long previous history of bambara groundnut production. It is considered necessary and advisable to inoculate the bambara groundnut seeds with effective rhizobium strain for good nodulation and nitrogen economy.

\section{REFERENCES}

Abate, A. (2008). Effect of nitrogen fertilizer and harvesting stage on yield and quality of natural pasture in Fogera district, North Western Ethiopia. MSc Thesis in Agriculture (Range Ecology and Management) Haramaya University, Haramaya 78pp.

A.O.A.C. (1980). Official Methods of Analysis, $13^{\text {th }}$ ed. Association of Official Analytical Chemists. Washington D. C. 1038pp

Chiezey, U.F., J.Y. Yayock and MK. Ahmed (1991). Effect of phosphorus and plant density on the yield and yield components of soybean (Glycine max L. Merrill). Crop Science Research 4(1): 11-18.

Food and Agricultural Organisation (FAO) (1992). Food and nutrition at the turn of the millenium. Information Division, FAO of the U.N. Nation. Rome, Italy. 2pp.

Goli, A.E. and N.Q. Ng (1988). Harvesting period of bambara groundnut for maximum yield and seed quality in the humid tropics. Agronomy Abstract of the 1988 Annual Meetings. 55pp.

Harper, F. (1983). Principles of Arable Crop Production. Granada Publishing Ltd., London. 336pp.

Johnson, D.T. (1968). Bambara groundnut. A review. Rhodesia Agricultural Journal 65(1): 1-14.

Jungerius, P.O. (1964). The soils of eastern Nigeria public service. Geologigue $d u$ Luxemboug XLVM: 185-198.

Karim, M.F. (1990). Growth, development and light inception of bambara groundnut and groundnut in relation to moisture. M.Sc Thesis. University of Nottingham.

Khaliger, (1987). Effect of nitrogen on nodulation and yield of soybean under two systems of production in Sudan. Journal of Agricultural Science Cambridge 108: 259-265.

Linnemann, A.R. (1990). Cultivation of bambara groundnut (Vigna subterranea (L.) Verdc.) in western province, Zambia. Tropical Crops Communication No. 16. 34pp.

Linnemann, A.R. (1991). Preliminary observations on photoperiodic regulation of phenological development in bambara groundnut (Vigna subterranea). Field Crops Research 26: 295-304.

Linnemann, A.R. (1993). Phenological development in bambara groundnut (Vigna subterranea) at constant exposure to photoperiods 10-16 hours. Annals of Botany 71: 445-452.

Linnemann, A.R. and S. Azam-Ali (1992). Bambara groundnut (Vigna subterranea (L.) Verde.). Unpublished. 120pp.

Malawi Government (1970). Other legumes. In: Annual Report of the Department of Agriculture (Part II) for the year 1964/65. Government Printer, Zomba, Malawi. 30pp.

National Research Council (1979). Bambara groundnut. In: Tropical Legumes, Resources for the Future. National Academy of Science, Washington, U.S.A. pp.47-53.

Ndor, N., Dauda, N.S., Abimuku, E.O., Azagaku, D.E. and Anzaku, H. (2012) Effect of phosphorus fertilizer and spacing on 
growth, nodulation count and yield of cowpea (Vigna unguiculata (L) Walp) in Southern Guinea savanna agroecological zone, Nigeria. Asian Journal of Agricultural Sciences 4 (4): $254-257$.

Olsen, F.J., Hamilton, G. and Elkins, D.M. (1975). Effect of nitrogen on nodulation and yield of soybean. Experimental Agriculture 11: 289-294.

Pearson, C.J., S. Masduki and J. Moenandir (1981). Effects of plant population and canopy manipulation on growth and yield of soybean in East Java Indonesia. Field Crops Research 3: 337-345.

Qayyum, S.M., A. Liaqat, M.A. Rajput (1983). Effect of row spacing and fertilizer combinations on the growth and yield of soybean (Glycine max L. Merrill). Tropical Grain Legume Bulletin 28: 2932.

Rachie, K.O. and P. Sylvestre (1977). Grain legumes. In: Leakey, C.L.A. and 3.B. Wills (eds.). Food Crops of the Lowland
Tropics. Oxford University Press Oxford, U.K. pp.41-74.

Rasul, F., Cheema, M.A., Sattar, A., Saleem, M.F. and Wahid, M.A. (2012). Evaluating the performance of three mungbean varieties grown under varying inter-row spacing. The Journal of Animal and Plant Sciences, 22(4): 1030 - 1035.

Rowland, J.R.J. (1993). Dryland farming in Africa. The Macmillan Press Ltd. London p. 85 86.

Summerfield, R.J. et al. (1975). Nitrogen nutrition of cowpea, Vigna unguiculata. Tropical Grain Legume Bulletin 1: 3-5.

Toungos, M.D., Sajo, A.A. and Gungula, D.T. (2009). Recommended fertilizer levels on Bambara groundnut (Vigna subterranea (L) Verde) in Yola Adamawa State, Nigeria. Agricultural Journal 4 (1): 14 21.

Vietrneyer, N.D. (1986). Lesser known plants of potential use in agriculture and forestry. Science 232: 1379-1384. 